\title{
TIME REWARD OF VALUE INVESTING: EVIDENCE FROM THE SOUTHEAST ASIA STOCK MARKETS
}

\author{
DOI: 10.17261/Pressacademia.2017.436 \\ JEFA-V.4-ISS.2-2017(1)-p.70-86
}

\section{Yosuke Kakinuma ${ }^{1}$}

${ }^{1}$ National Institute of Development Administration (NIDA), Bangkapi, Bangkok 10240, Thailand. yuky07@gmail.com.

\section{To cite this document}

Kakinuma, Y. (2017). Time reward of value investing: evidence from the Southeast Asia stock markets. Journal of Economics, Finance and

Accounting (JEFA), V.4, Iss.2, p.70-86.

Permanent link to this document: http://doi.org/10.17261/Pressacademia.2017.436

Copyright: Published by PressAcademia and limited licenced re-use rights only.

\begin{abstract}
Purpose- This study tests the effectiveness of value investing and its relation to the length of investment horizon in Malaysia, Singapore, and Thailand stock markets as well as the ASEAN market as a whole. Two simple financial ratios, namely, Price-to-Earning (PE) ratio and Price-to-Book (PE) ratio, are employed to see if they represent value premium in a long-term investment.

Methodology- A simulation methodology that randomly selects an investment date is applied which effectively eliminates market timing bias. Portfolios sorted by PE and PB ratios are formed on a randomly chosen date and held for different periods of time. Additionally, FamaMcbeth (1973) regression checks a robustness of value premium of PE and PB ratios.

Findings- Portfolios constructed with low PE and PB ratio generate higher returns and form efficient portfolios with better risk-return trade-off. In a long-term investment, PE and PB are indicators of value premium. Also, the ASEAN Link provides an excellent opportunity for international diversification.

Conclusion- Value investors are rewarded for holding portfolios with low PE and PB stocks for a long period of time. Furthermore, investors should construct portfolios with stocks from different markets to fully take advantage of international diversification, which significantly reduces investment risk.
\end{abstract}

Keywords: Value investing, long-term investment, international diversification, financial simulation, emerging markets. JEL Codes: G11, G15, G17

\section{INTRODUCTION}

Finding undervalued stocks is a basic principle of value investing. Benjamin Graham (1949), who is often referred as "the father of value investing," stresses an importance to secure "margin of safety," or in other words, the difference between a firm's intrinsic value and the market price. Previous researches suggest that, among other financial ratios, Price-to-Earning (PE) ratio (Basu, 1977) and Price-to-Book (PB) ratio (Fama \& French, 1992) are the key indicators of undervalued stocks. Today, the both ratios are popular and widely-available ratios for general investors.

Besides the margin of safety, another important aspect of value investing is a long-term investment horizon. Securing the margin of safety does not guarantee an instant profit but value investors are rewarded for holding stocks for a long term. Stock market is extremely volatile in the short-run, but in the long-run, market price should get closer to a firm's intrinsic value.

In 2012, the ASEAN countries declared to establish the AEAN Exchange, a collaboration of securities exchanges of the ASEAN member countries, namely Singapore, Malaysia, Thailand, Vietnam, Philippines, and Indonesia (www.aseanexchanges.org). Its aim is to integrate the each countries' exchanges into one capital market. The ASEAN Link is the platform for the single exchange market. As of April 2016, investors are able to trade securities on the Singapore 
Exchanges, the Bursa Malaysia, and the Stock Exchange of Thailand, via the ASEAN Link. This means that an investor who has an account in the ASEAN Link is able to trade shares of Singapore, Malaysia, and Thailand, which together represents $70 \%$ of market capitalization of the ASEAN Exchange, in a single account. More member countries are expected to join this link in the near future, which creates a huge capital market in the Southeast Asia.

The ASEAN Link provides an excellent opportunity for the investors in the region to access to international diversification. On the contrary to Markowitz's efficient market portfolio theory (1952) which proposes that risk-return optimization is realized through diversification, Gaudecker (2015) points out that general households tend to underdivesify, and the loss from the underdiversification can be significant over life time.

Table 1 shows the Pearson correlation coefficients of daily returns of the FTSE Bursa Malaysia EMAS index (FBMEMAS), the FTSE ST All SHARE index (FSTAS), and the SET index (SET) for the period from January 2000 to December 2015. The FBMEMAS represents the top $98 \%$ of stocks listed on the Bursa Malaysia by market capitalization. The FSTAS represents $98 \%$ of Singapore market capitalization. The SET is comprised of all the stocks listed on the Stock Exchange of Thailand.

Table 1: Correlation Matrix of Daily Market Index Returns

\begin{tabular}{llll}
\hline & $\begin{array}{l}\text { FBMEMAS } \\
\text { (Malaysia) }\end{array}$ & $\begin{array}{l}\text { FTAS } \\
\text { (Singapore) }\end{array}$ & $\begin{array}{l}\text { SET } \\
\text { (Thailand) }\end{array}$ \\
\hline FBMEMAS & 1.0000 & & \\
FTAS & $0.5101^{* * *}$ & 1.0000 & 1.0000 \\
SET & $0.3813^{* * *}$ & $0.4893^{* * *}$ &
\end{tabular}

$* * *$ denotes significance at $0.1 \%$

Although the three countries are geographically close and economic ties are strong, the behavior of the each market is a different story. The correlation of daily returns between the Malaysia market and the Singapore market is only 0.51 although the two countries share the border and are the largest trade partners to the each other. The correlation of daily idex returns is even lower at 0.38 between the Malaysia market and the Thailand market. Thus, the relatively low correlation of the stock returns in the three markets provides the chance to form a better diversified portfolio.

In this study, I test a simple stock screening strategy by PE and PB ratios with a simulation method which portfolios are constructed on randomly selected dates. Returns are calculated for different holding periods to see if value investors are rewarded for longer time investment horizon. Additionally, the returns of the portfolios are compared to those of market benchmark indices. The advantage of international diversification through the ASEAN Link is also examined.

\section{LITERATURE REVIEW}

Graham (1949) pioneered in the field of value investing, and many followed his path to pursue value premium using financial ratios. Basu (1977) was the first to find out that stocks with low PE ratios yield a higher return. The low PE stocks even generated higher risk-adjusted return backed by higher Jensen's alpha and Shape ratio. Chan, Hamao, and Lakonishok (1991) argue that Book to Market ratio (B/M) and Cash Flow Yield (CFY) are the two significant variables that explain excess return in the Japanese market. "Size-effect" is that smaller firms in term of market capitalization outperform bigger firms (Banz, 1981). Fama and French (1992) revealed a stunning outcome that challenges the capital asset pricing model. The Fama-French 3-factor model with market return, size-effect, and B/M remains as one of the most powerful asset pricing model today. Novy-Marx (2013) argues that gross profitabiliy, gross profit-to-assets, is as powerful measure of value premum as B/M. Fama and French (2015) incorporate profitability and investment factors in the 3-factor model and propose a new 5 -factor model. Several studies state that value stocks respond diffrenly to the underlying economic condtions (Black and McMillan, 2004, 2005: Amman and Verhofen, 2006; Gulen, Xing, and Zhang, 2011; Sarwar, Mateus, and Todorovic, 2017). Value stocks are counter-cyclcial (Chen, Petkova and Zhang, 2008), meaning that value stocks perform much better during economic recessions than during expansions. Value investing is effective not only in the US market but in the international market as well (Bauman, Conover, and Miller, 1998; Sarewiwattahan, 2013).

International diversification is effective in reducing portfolio risk and increasing expected return. Solnik (1974) showed that significant reduction in risk can be achieved with portfolio diversification in foreign stocks as well as domestic common securities in the total of eight countries in the US and Europe. Lessard (1976) presented that, at the same level of risk, the world portfolio which is consisted of value-weighted 16 major national indices in the world generates a higher return than a single national index.

\section{DATA AND METHODOLOGY}

I obtained the following information on the Bursa Malaysia, the Singapore Exchange, and the Stock Exchange of Thailand from Thomson Reuters' Datastream: 1) daily stock prices listed on the each market, 2) daily PE ratio of the stocks, 3) daily 
PB ratio of the stocks, and 4) daily index prices of the each market benchmearks. The testing period is 16 years starting from January 3, 2000 to December 31, 2015. During the 16 years of the test period, there were 4,174 trading days for the each stock market.

The total number of stocks available for this research is 655 in the Malaysia market, which are the constituents of FTSE Bursa Malaysia EMAS index (Datastream code-LKLSEMAS). For the Singapore market, I obtained the total of 806 stocks which represent all stocks listed on the Singapore Exchange (Datastream code-FSINQ). The total number of stocks in the Thai market is 554, which are the constituents of the SET index (Datastream code-LBNGKSET). Table 2 shows descriptive statistics of PB and PE ratios in the three markets. In the all three markets, there are some extreme samples, such as a stock with PE ratio as high as 390 in Thailand. Thus, there is a gap between the mean and the medium. Surprisingly, correlation between PB and PE are very small although statistical significance is strong. This suggests that a stock with low PB can have a high PE and vice versa.

Table 2: Descriptive Statistics of PB and PE Ratios in the Malaysia, Singapore and Thailand Markets

\begin{tabular}{llllllll}
\hline & Mean & Median & SD & Min & Max & Observation & $\begin{array}{l}\text { Correlation } \\
\text { PB and PE }\end{array}$ \\
\hline Malaysia & & & & & & & \\
PB & 1.24 & 0.84 & 2.30 & -49.77 & 82.43 & $2,733,970$ & $0.056^{* * *}$ \\
PE & 17.40 & 11.30 & 25.06 & 0.00 & 199.30 & $2,733,970$ & \\
Singapore & & & & & & & \\
PB & 1.59 & 0.98 & 4.52 & -89.50 & 102.50 & $3,364,244$ & $0.018^{* * *}$ \\
PE & 16.92 & 10.80 & 22.90 & 0.00 & 390.68 & $3,364,244$ & \\
Thailand & & & & & & & \\
PB & 1.66 & 1.11 & 2.90 & -70.10 & 99.80 & $2,312,396$ & $0.162^{* * *}$ \\
PE & 17.40 & 11.00 & 24.58 & 0.00 & 299.90 & $2,312,396$ & \\
& $* * *$ denote Pearson correlation significance at $0.1 \%$ &
\end{tabular}

A simulation technique on random date portfolio formation is employed for this study, which Rousseau and Rensburg (2004) used for a test in the South African market. The random date selection avoids a market timing bias (Muller, 1999).

First, on a randomly selected date, stocks are ranked according to PE ratio, PB ratio, and the both combined, in ascending order. Then stocks are divided into 5 groups by the ranking. Group 1 contains the first $20 \%$ of the lowest PE or PB stocks, which are value stocks. Group 5 gets the top $20 \%$ of the highest PE or PB stocks, which are growth stocks. The $6^{\text {th }}$ group is formed by Negative PE and negative PB stocks. Stocks that PE or PB ratios are unavailable on the randomly selected data are excluded. Property funds, REIT, and investment trusts are eliminated from this portfolio formation process. Next, from the each group, 30 stocks are randomly selected and six equally-weighted portfolios are constructed. Thus, each portfolios are consisted of 30 stocks. For the PE and PB combined portfolios, the sum of the each ratio's rank is used for the ranking. If either ratio is unavailable on a given day, the stock is eliminated from this combined-rank portfolio formation. This process is repeated 500 times. For the ASEAN market, portfolios are constructed from all the stocks in Malaysia, Singapore, and Thailand.

Monthly returns are obtained for the each portfolios. Then annualized returns and standard deviations are calculated for the five different holding periods of 6-month, 1 year, 1.5 year, 2 years, and 2.5 years. This process is repeated for the Thai, Malaysia, Singapore, and the ASEAN markets.

The portfolio returns are compared to the each market's benchmark indices, namely the FTSE Bursa Malaysia EMAS index (FBMEMAS) for Malaysia, the FTSE ST All SHARE index (FSTAS) for Singapore, and the SET index (SET) for Thailand.

In order to check robustness of the effects of PE and PB ratios on stock returns in a long term investment, which I define as 18 months, the following equation is tested with Fama-Macbeth (1973) regression.

$$
\text { Annualized } R_{i t+k}=\propto+\beta_{1} B t M_{i t}+\beta_{2} E Y_{i t}+\varepsilon_{t} \quad k=(18 \text { months })
$$

where $R_{i t+k}$ is an annualized return of stock ${ }_{\mathrm{i}}$ for a holding period ${ }_{\mathrm{k}}$ from date ${ }_{\mathrm{t}} \cdot \mathrm{k}$ takes 18 months (1.5 year), thus $R_{i t+k}$ is an annualized return of stock ${ }_{\mathrm{i}}$ for a holding periods of 1.5 year. $B t M_{i t}$ is book-to-market ratio of stock ${ }_{\mathrm{i}}$ on date ${ }_{\mathrm{t}}, E Y_{i t}$ is earning yield of stock ${ }_{i}$ at month ${ }_{t}$. Note that book-to-market ratio is a reciprocal of PB and earning yield is a reciprocal of PE. Value stocks generally have low PB and low PE. In other words, value stocks have high book-to-market and high earning 
yield. This conversion is made for a purpose of easier understanding of coefficients of $\beta_{1}$ and $\beta_{2}$ in the regression equation. I estimate the $\beta_{1}$ and $\beta_{2}$ within the each year from 2000 to 2013 as well as across all the years.

\section{FINDINGS AND DISCUSSIONS}

\subsection{The Malaysia Market}

Table 3 reports the result of the Malaysia market. The returns shown in the table are average annualized returns for the different holding periods which start from randomly selected 500 trading dates. Standard deviations are also annualized figures. T-values are for the difference in the average return between the portfolios and the market (FBMEMAS). As the holding period gets longer, values stocks with low PE and low PB which are assigned to Group 1 first then Group 2 start outperforming growth stocks with high PE and high PB in Group 5. The difference in the average return between the value portfolios and the market gets statistical significance once the holding period reaches 18 months. The two portfolios, Group 1 and 2, consisted of the lowest PE stocks selected on randomly selected dates generate higher returns than the market at $5 \%$ or lower significance level for the holding period of 18 months or longer. Value portfolio with the lowest PB gets a statistically significant higher return when the holding period hits 24 months. For the value stocks selected by both $P E$ and $\mathrm{PB}$, the picture is similar to the raking by PE only. Group 1 and Group 2 portfolio outperform the market with the statistical significance after 18 months. The market generates relatively satisfactory average returns ranging from approximately $5 \%$ to $12 \%$ depending on a holding period, yet value stocks manage to outperform the market after held for 18 months or longer.

Figure 1 and 2 graphically illustrate the portfolio and the market returns for the holding period of 6-month and 18-mont respectively. None of the returns show a statistical significance in the 6-montht period. Figure 2 indicates that within the portfolio selection criteria, which are $\mathrm{PE}, \mathrm{PB}$, and the both $\mathrm{PE}$ and $\mathrm{PB}$, value stocks clearly outperform growth stocks.

Figure 3 plots value portfolio (Group 1) and growth portfolio (Group 5) in risk-return pane. Values stocks, mostly PE only and the both PE and PB, with holding periods longer than 18 months form efficient portfolios which are circled with normal line in the pane. They generate higher returns at certain levels of risks with standard deviations ranging from approximately $10 \%$ to $20 \%$. At the almost same level of risks, growth stocks generate inferior returns, which are circled with dashed line. Most PB value stocks produce higher return with higher risk while PB growth stocks generate lower return with lower risk.

Table 3: Average Returns and Standard Deviation of the Portfolios and the Market in Malaysia

\begin{tabular}{lllllllll} 
Portfolio Group & & $\mathbf{1}$ & $\mathbf{2}$ & $\mathbf{3}$ & $\mathbf{4}$ & $\mathbf{5}$ & Negative & Market \\
\hline \hline \multirow{2}{*}{$\begin{array}{l}\text { Rank by PE } \\
\text { 6-month }\end{array}$} & & & & & & & & \\
& Return & -0.0144 & 0.1566 & -0.0383 & 0.0342 & -0.0380 & -0.0039 & 0.0702 \\
& t-value & -0.6572 & 0.8143 & -0.9712 & -0.3615 & -1.1278 & -0.2890 & - \\
12-month & SD & 0.1510 & 0.0973 & 0.0756 & 0.0655 & 0.0924 & 0.1848 & 0.1085 \\
& Return & 0.2573 & 0.2962 & 0.1908 & 0.1753 & 0.1763 & 0.2730 & 0.1179 \\
& t-value & 1.0367 & 1.4163 & 0.7894 & 0.7083 & 0.6018 & 0.6272 & - \\
18-month & SD & 0.2243 & 0.1979 & 0.1486 & 0.1142 & 0.1597 & 0.3171 & 0.1254 \\
& Return & $0.3291 *$ & $0.3640 * *$ & 0.1810 & 0.1552 & 0.1944 & 0.1674 & 0.0910 \\
& t-value & 2.3035 & 2.8006 & 1.2789 & 1.0715 & 1.3408 & 0.4561 & - \\
24-month & SD & 0.1901 & 0.1686 & 0.1250 & 0.0981 & 0.1341 & 0.2624 & 0.1045 \\
& Return & $0.2528 *$ & $0.2729 * *$ & 0.1239 & 0.1066 & 0.1223 & 0.1362 & 0.0522 \\
& t-value & 2.4566 & 2.8199 & 1.3122 & 1.0650 & 1.1827 & 0.6555 & - \\
30-month & SD & 0.1772 & 0.1605 & 0.1212 & 0.0994 & 0.1246 & 0.2334 & 0.0976 \\
& Return & $0.2022 *$ & $0.1952 *$ & 0.0847 & 0.0799 & 0.0933 & 0.1068 & 0.0511 \\
& t-value & 2.0460 & 2.0341 & 0.7035 & 0.6272 & 0.8192 & 0.5371 & - \\
\hline 6-monk by PB & SD & 0.1768 & 0.1630 & 0.1183 & 0.1033 & 0.1204 & 0.2144 & 0.1000 \\
\hline & & & & & & & & \\
& Return & 0.0516 & -0.1157 & 0.0326 & 0.0446 & -0.0682 & 0.1774 & 0.0702 \\
& t-value & -0.1940 & -0.0349 & -0.1863 & -0.2224 & -1.4132 & 0.3090 & -
\end{tabular}




\begin{tabular}{|c|c|c|c|c|c|c|c|c|}
\hline & SD & 0.0470 & 0.0889 & 0.1438 & 0.0569 & 0.1164 & 0.1843 & 0.1085 \\
\hline \multirow[t]{3}{*}{ 12-month } & Return & 0.3697 & 0.2547 & 0.2524 & 0.1539 & 0.1521 & 0.2489 & 0.1179 \\
\hline & t-value & 1.0688 & 0.9187 & 0.7593 & 0.4656 & 0.3962 & 0.7273 & - \\
\hline & SD & 0.3209 & 0.2240 & 0.2408 & 0.1149 & 0.1515 & 0.1462 & 0.1254 \\
\hline \multirow[t]{3}{*}{ 18-month } & Return & 0.3811 & 0.2790 & 0.2217 & 0.1247 & 0.0756 & 0.1289 & 0.0910 \\
\hline & t-value & 1.6937 & 1.6121 & 1.1076 & 0.6085 & -0.2386 & 0.3014 & - \\
\hline & SD & 0.2714 & 0.2017 & 0.1962 & 0.0952 & 0.1274 & 0.1321 & 0.1045 \\
\hline \multirow[t]{3}{*}{ 24-month } & Return & $0.2981 *$ & 0.2065 & 0.1912 & 0.0904 & 0.0251 & 0.0890 & 0.0522 \\
\hline & t-value & 1.8491 & 1.6435 & 1.5329 & 0.8727 & -0.5118 & 0.3867 & - \\
\hline & SD & 0.2481 & 0.1904 & 0.1729 & 0.0891 & 0.1152 & 0.1165 & 0.0976 \\
\hline \multirow[t]{3}{*}{ 30-month } & Return & 0.2375 & 0.1508 & 0.1660 & 0.0557 & 0.0174 & 0.0684 & 0.0511 \\
\hline & $\mathrm{t}$-value & 1.6675 & 1.2279 & 1.5408 & 0.1192 & -0.7673 & 0.2189 & - \\
\hline & SD & 0.2373 & 0.1895 & 0.1612 & 0.0888 & 0.1110 & 0.1064 & 0.1000 \\
\hline \multicolumn{9}{|c|}{ Rank by PE \& PB } \\
\hline \multirow[t]{3}{*}{ 6-month } & Return & 0.1518 & 0.1218 & -0.0286 & 0.0073 & 0.0618 & 0.0791 & 0.0702 \\
\hline & t-value & 0.6116 & 0.7994 & -0.9661 & -0.6570 & -0.0565 & 0.0278 & \\
\hline & SD & 0.0917 & 0.1100 & 0.0907 & 0.0791 & 0.1205 & 0.1610 & 0.1085 \\
\hline \multirow[t]{3}{*}{ 12-month } & Return & 0.3044 & $0.3163^{*}$ & 0.1066 & 0.1908 & 0.0847 & 0.3238 & 0.1179 \\
\hline & $\mathrm{t}$-value & 1.3540 & 2.4333 & -0.1468 & 0.7153 & -0.3720 & 1.0053 & \\
\hline & SD & 0.2140 & 0.1628 & 0.1586 & 0.1798 & 0.1254 & 0.2128 & 0.1254 \\
\hline \multirow[t]{3}{*}{ 18-month } & Return & $0.3391^{*}$ & $0.3099 * * *$ & 0.1318 & 0.1453 & 0.0757 & 0.1781 & 0.0910 \\
\hline & t-value & 2.5583 & 3.7285 & 0.5717 & 0.7008 & -0.2571 & 0.5967 & \\
\hline & SD & 0.1776 & 0.1343 & 0.1427 & 0.1546 & 0.1032 & 0.1883 & 0.1045 \\
\hline \multirow[t]{3}{*}{ 24-month } & Return & $0.2615^{* *}$ & $0.2600 * * *$ & 0.0974 & 0.1390 & 0.0484 & 0.1042 & 0.0522 \\
\hline & t-value & 2.5648 & 4.0237 & 0.7394 & 1.1565 & -0.0835 & 0.4668 & \\
\hline & SD & 0.1722 & 0.1303 & 0.1375 & 0.1528 & 0.0935 & 0.1677 & 0.0976 \\
\hline \multirow[t]{3}{*}{ 30-month } & Return & $0.2293 * *$ & $0.2022 * *$ & 0.0820 & 0.0859 & 0.0448 & 0.0762 & 0.0511 \\
\hline & t-value & 2.5272 & 3.1380 & 0.5684 & 0.5372 & -0.1589 & 0.2781 & \\
\hline & SD & 0.1648 & 0.1360 & 0.1429 & 0.1486 & 0.0906 & 0.1530 & 0.1000 \\
\hline
\end{tabular}

$*, * *, * * *$ denote significance at $5 \%, 1 \%$, and $0.1 \%$ respectively

Figure 1: 6-Month Returns of the Malaysia Market

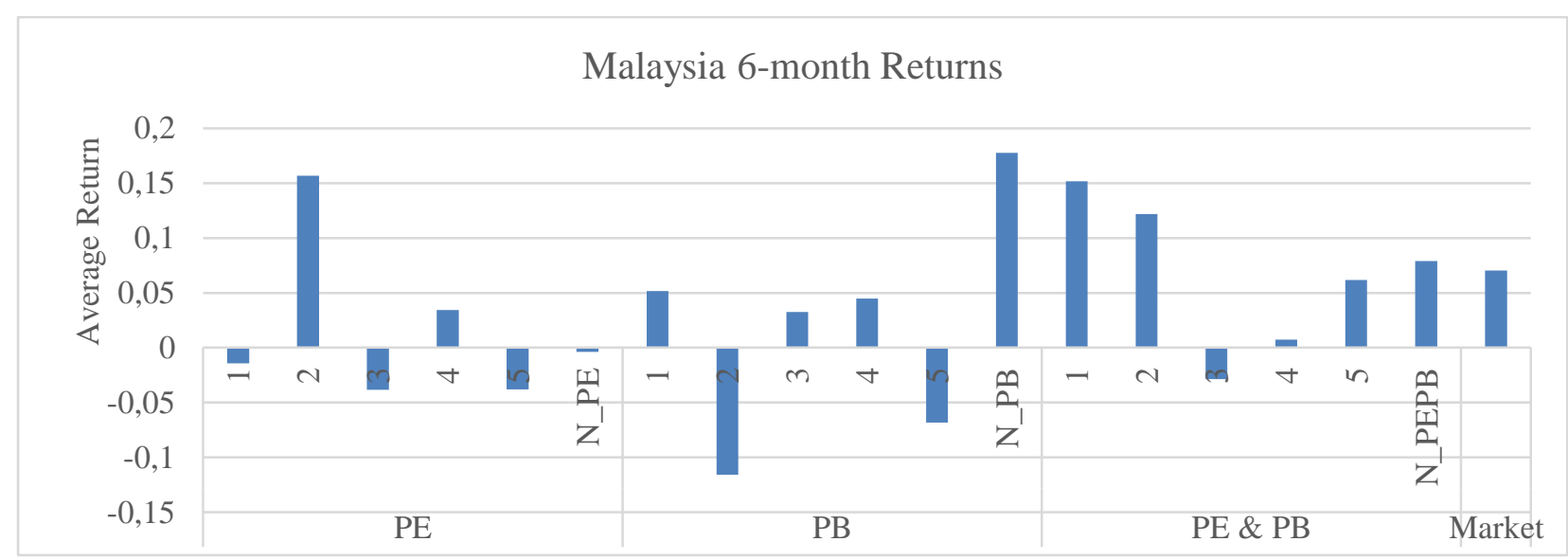


Figure 2: 18-Month Returns of the Malaysia Market

Malaysia 18-month Returns

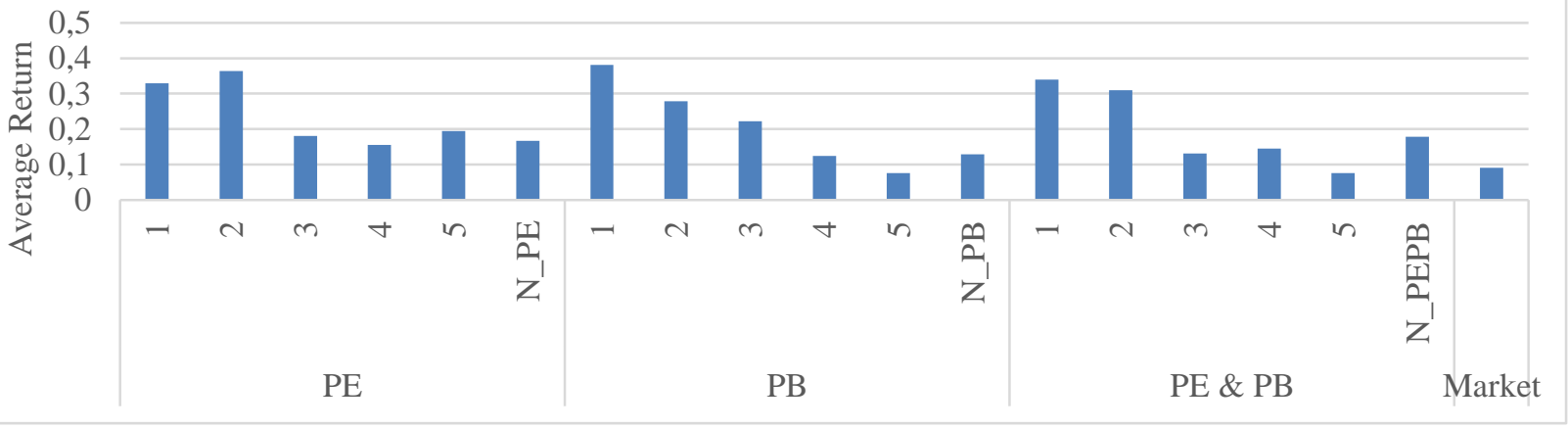

Table 4 reports the result of Fama-Macbeth (1974) regression. The mean coefficients of BtM and EY across the all years are both positively significant, suggesting that value stocks produce higher returns in a long term investment. Overall, the regression result supports the simulation outcome of Table 3.

When looking at the result of the individual years, BtM shows more consistency and it is positive with statistical significance in 9 out of 14 years, whereas EY is positively significant in only 7 years. In 2008, 2012 and2013, EY is negatively significant, which means value stocks with high earning yield led to lower returns in the particular three years.

Figure 3: Risk-Return Plot for Value Portfolios and Growth Portfolios of the Malaysia Market

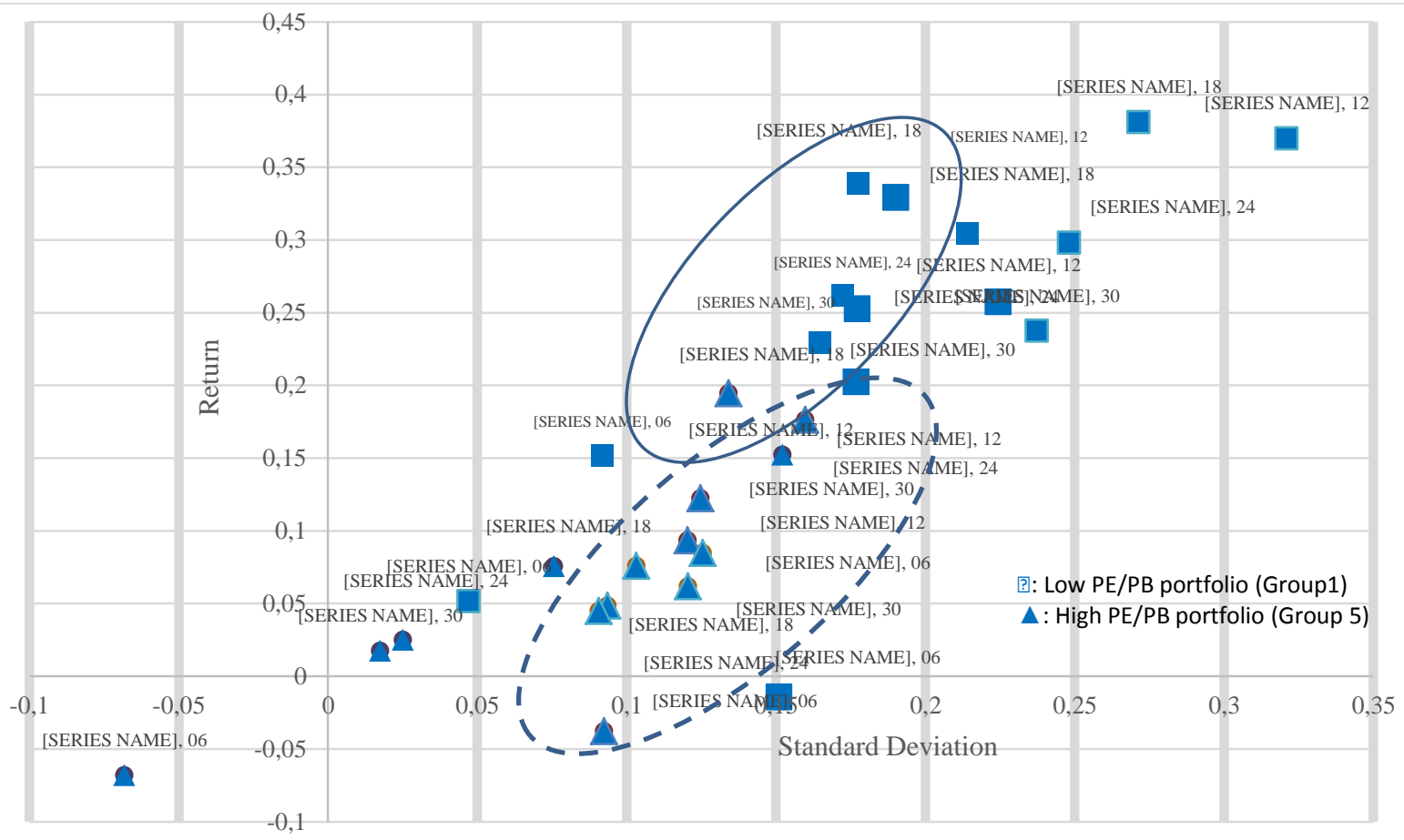

Table 4: Regression Results for the Malaysia Market

The table represents the result of Fama-Macbeth (1973) regression. The dependent variable is annualized 1.5-year stock returns. The independent variables are BtM, book-to-market ratio, and $\mathrm{EY}$, earning yield, which are reciprocal of $\mathrm{PB}$ and $\mathrm{PE}$ respectively.

Annualized $R_{i t+k}=\propto+\beta_{1} B t M_{i t}+\beta_{2} E Y_{i t}+\varepsilon_{t} \quad k=(18$ months $)$ 


\begin{tabular}{llll} 
Year & Constant & BtM & EY \\
\hline \hline 2000 & $-0.2865^{* * *}$ & -0.0118 & $0.3792^{* *}$ \\
2001 & 0.0201 & $0.0176^{* * *}$ & 0.0305 \\
2002 & $0.4650^{*}$ & $-0.1255^{* * *}$ & $0.2272^{* * *}$ \\
2003 & $0.073^{* * *}$ & 0.0084 & $0.1115^{* *}$ \\
2004 & $-0.1660^{* * *}$ & $0.0109^{*}$ & $0.0827^{* * *}$ \\
2005 & $-0.0833^{* * *}$ & $0.03596^{* * *}$ & $0.0435^{* * *}$ \\
2006 & $0.1009^{* * *}$ & $0.0582^{* * *}$ & $0.1268 * * *$ \\
2007 & $-0.1573^{* * *}$ & $0.03225^{* * *}$ & -0.0248 \\
2008 & $-0.1318^{* * *}$ & 0.0041 & $-0.0673^{* * *}$ \\
2009 & $0.1600^{* * *}$ & $0.0151^{*}$ & $0.0219 *$ \\
2010 & $0.0475^{* *}$ & $0.0215^{* * *}$ & -0.0158 \\
2011 & $-0.0112^{*}$ & $0.0087^{* * *}$ & 0.001 \\
2012 & $0.0454^{* * *}$ & $0.02458^{* * *}$ & $-0.02928 * * *$ \\
2013 & $0.0627^{* * *}$ & $0.0532^{* * *}$ & $-0.0108^{* *}$ \\
\hline Mean & -0.191 & $0.0185^{* * *}$ & $0.0590^{* * *}$ \\
$* * *, * * *$ denote significance at $5 \%, 1 \%$, and $0.1 \%$ respectively
\end{tabular}

\subsection{The Singapore Market}

The simulation result for the Singapore market is reported in Table 5. While value portfolios with low PE and/or PB outperform the market index regardless the length of holding periods, none of the portfolios gets statistically significant returns. This suggests that the higher returns of value stocks come from higher standard deviations of the portfolios. In other words, the higher return than the market is due to taking higher risk. The statistical insignificance implies the higher degree of efficiency of the Singapore market. On the randomly selected dates in this study, the Singapore market did not do well with the average returns falling in the range from $-3 \%$ to $4 \%$, yet the standard deviation was lower than the portfolios which outperformed the market.

Figure 4 and Figure 5 show the 6-month and 18-month returns of the all the portfolios and the market. The difference in the returns between the value stocks and growth stocks becomes more prominent as the holding period gets longer. Hence, value investors are likely to be rewarded for holding stocks for a longer period of time. Some growth stocks that form Group 4 and Group 5 portfolios and negative PE and/or PB portfolios posted negative returns. This connotes that value investing can be a defensive strategy against downside risk.

Table 5: Average Returns and Standard Deviation of the Portfolios and the Market in Singapore

\begin{tabular}{|c|c|c|c|c|c|c|c|c|}
\hline \multicolumn{2}{|c|}{ Portfolio Group } & 1 & 2 & 3 & 4 & 5 & Negative & Market \\
\hline \multicolumn{9}{|l|}{ Rank by PE } \\
\hline \multirow[t]{3}{*}{ 6-month } & Return & 0.1735 & 0.1622 & 0.0093 & 0.0497 & -0.0545 & -0.2474 & -0.0069 \\
\hline & t-value & 0.7861 & 1.8440 & 0.3673 & 0.6967 & -0.4204 & -0.8792 & - \\
\hline & SD & 0.1479 & 0.0796 & 0.1047 & 0.1153 & 0.0591 & 0.2372 & 0.1249 \\
\hline \multirow[t]{3}{*}{ 12-month } & Return & 0.2543 & 0.1860 & 0.0459 & 0.1027 & 0.0666 & 0.1668 & 0.0379 \\
\hline & t-value & 0.7410 & $2.3689 *$ & 0.1831 & 0.9963 & 0.3319 & 0.3566 & - \\
\hline & SD & 0.2736 & 0.0683 & 0.0900 & 0.0842 & 0.0640 & 0.3567 & 0.1037 \\
\hline \multirow[t]{3}{*}{ 18-month } & Return & 0.1264 & 0.1081 & -0.0411 & -0.0158 & 0.0352 & 0.0319 & 0.0076 \\
\hline & t-value & 0.7410 & 1.5749 & -1.1061 & -0.4055 & 0.4093 & 0.1004 & - \\
\hline & SD & 0.2442 & 0.0897 & 0.0959 & 0.0888 & 0.0679 & 0.3033 & 0.0989 \\
\hline \multirow[t]{2}{*}{ 24-month } & Return & 0.1422 & 0.0950 & -0.0136 & -0.0096 & 0.0428 & 0.0417 & 0.0232 \\
\hline & $t$-value & 0.7900 & 1.2803 & -1.0385 & -0.6713 & 0.3287 & 0.0922 & - \\
\hline
\end{tabular}




\begin{tabular}{|c|c|c|c|c|c|c|c|c|}
\hline & SD & 0.2187 & 0.0873 & 0.0981 & 0.0911 & 0.0612 & 0.2946 & 0.0981 \\
\hline \multirow[t]{3}{*}{ 30-month } & Return & 0.2517 & 0.0183 & -0.0602 & -0.0631 & -0.0137 & -0.0323 & -0.0318 \\
\hline & $t$-value & 1.3031 & 0.9605 & -0.8467 & -0.7455 & 0.3526 & -0.0033 & - \\
\hline & SD & 0.3533 & 0.1364 & 0.1141 & 0.1102 & 0.0862 & 0.2940 & 0.1227 \\
\hline \multicolumn{9}{|c|}{ Rank by PB } \\
\hline \multirow[t]{3}{*}{ 6-month } & Return & 0.1172 & 0.4032 & 0.0117 & -0.0557 & 0.0345 & 0.0962 & -0.0069 \\
\hline & $t$-value & 1.1303 & 1.6464 & 0.1496 & -0.8656 & 0.1029 & 0.4275 & - \\
\hline & SD & 0.1006 & 0.2512 & 0.1415 & 0.1179 & 0.2987 & 0.1194 & 0.1249 \\
\hline \multirow[t]{3}{*}{ 12-month } & Return & 0.3589 & 0.2342 & 0.0882 & 0.0267 & 0.0569 & 0.0060 & 0.0379 \\
\hline & $t$-value & 0.9075 & 1.3217 & 0.5515 & -0.1969 & 0.0803 & -0.2389 & - \\
\hline & SD & 0.3456 & 0.1820 & 0.1295 & 0.1079 & 0.2279 & 0.0951 & 0.1037 \\
\hline \multirow[t]{3}{*}{ 18-month } & Return & 0.1674 & 0.1803 & -0.0251 & -0.0702 & -0.0784 & -0.0020 & 0.0076 \\
\hline & $t$-value & 0.6620 & 1.3732 & -0.4618 & -1.5264 & -0.5032 & -0.0975 & - \\
\hline & SD & 0.2979 & 0.1739 & 0.1270 & 0.1030 & 0.2266 & 0.0989 & 0.0989 \\
\hline \multirow[t]{3}{*}{ 24-month } & Return & 0.1451 & 0.1439 & -0.0262 & -0.0142 & -0.0698 & 0.0204 & 0.0232 \\
\hline & $t$-value & 0.6112 & 1.1686 & -0.8275 & -0.7156 & -0.6125 & -0.0293 & - \\
\hline & SD & 0.2912 & 0.1607 & 0.1269 & 0.1091 & 0.2435 & 0.1037 & 0.0981 \\
\hline \multirow[t]{3}{*}{ 30-month } & Return & 0.0938 & 0.0752 & -0.0443 & -0.0845 & -0.1245 & -0.0166 & -0.0318 \\
\hline & $t$-value & 0.7505 & 1.1618 & -0.2020 & -1.1619 & -0.7392 & 0.1830 & - \\
\hline & SD & 0.2898 & 0.1841 & 0.1624 & 0.1276 & 0.2436 & 0.1079 & 0.1227 \\
\hline \multicolumn{9}{|c|}{ Rank by PE \& PB } \\
\hline \multirow[t]{3}{*}{ 6-month } & Return & 0.1868 & 0.0873 & 0.2311 & -0.0735 & 0.0716 & -0.0502 & -0.0069 \\
\hline & $\mathrm{t}$-value & 1.1597 & 0.8336 & 0.8506 & -0.4084 & 0.3310 & -0.1128 & - \\
\hline & SD & 0.0742 & 0.0789 & 0.2567 & 0.1435 & 0.1797 & 0.1610 & 0.1249 \\
\hline \multirow[t]{3}{*}{ 12-month } & Return & 0.1125 & 0.1139 & 0.2023 & 0.0938 & 0.0162 & 0.0639 & 0.0379 \\
\hline & $t$-value & 0.6586 & 1.0122 & 0.9469 & 0.4434 & -0.1428 & 0.0991 & - \\
\hline & SD & 0.0757 & 0.0886 & 0.1890 & 0.1419 & 0.1355 & 0.2128 & 0.1037 \\
\hline \multirow[t]{3}{*}{ 18-month } & Return & 0.0933 & 0.0346 & 0.0425 & 0.0276 & -0.1859 & -0.0040 & 0.0076 \\
\hline & $\mathrm{t}$-value & 0.9613 & 0.4651 & 0.2797 & 0.2276 & -1.5199 & -0.0593 & - \\
\hline & SD & 0.0945 & 0.0857 & 0.1736 & 0.1272 & 0.1668 & 0.1883 & 0.0989 \\
\hline \multirow[t]{3}{*}{ 24-month } & Return & 0.0928 & 0.0345 & 0.0620 & 0.0210 & -0.1058 & 0.0657 & 0.0232 \\
\hline & t-value & 0.9930 & 0.2106 & 0.4005 & -0.0302 & -1.1028 & 0.2356 & - \\
\hline & SD & 0.0940 & 0.0843 & 0.1604 & 0.1177 & 0.1819 & 0.1677 & 0.0981 \\
\hline \multirow[t]{3}{*}{ 30-month } & Return & 0.0232 & -0.0089 & -0.0585 & -0.0228 & -0.1302 & 0.0332 & -0.0318 \\
\hline & $t$-value & 0.8111 & 0.5051 & -0.3140 & 0.1371 & -0.9250 & 0.4344 & - \\
\hline & SD & 0.1068 & 0.1119 & 0.1727 & 0.1297 & 0.2151 & 0.1530 & 0.1227 \\
\hline
\end{tabular}

* denotes significance at $5 \%$ 
Figure 4: 6-Month Returns of the Singapore Market

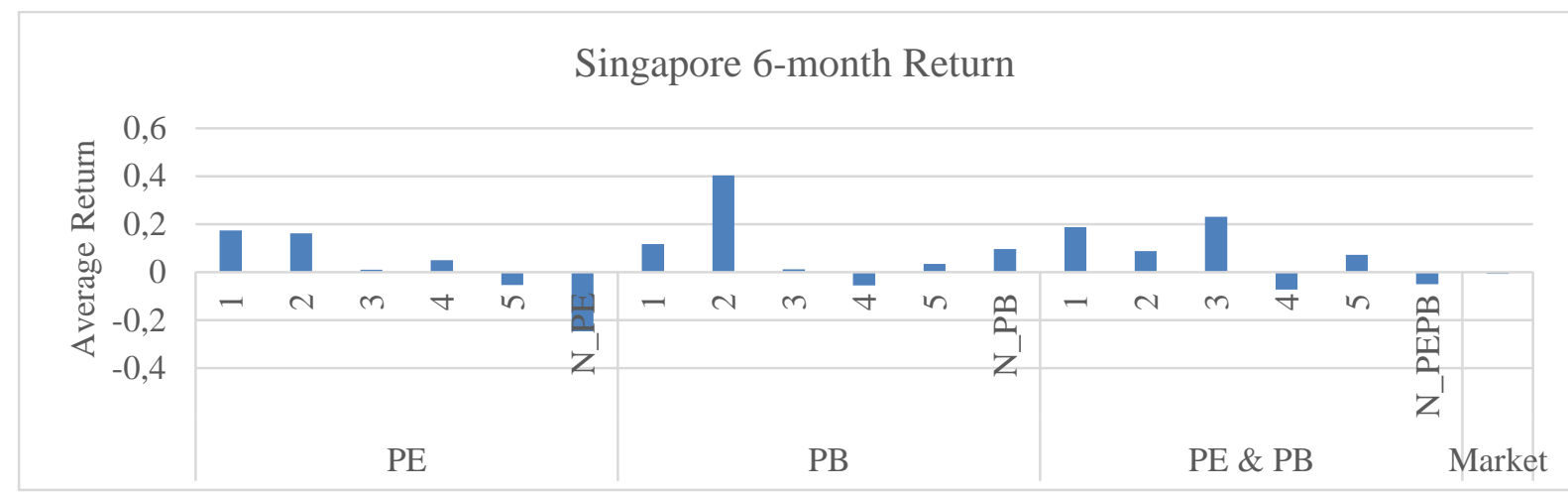

Figure 5: 18-Month Returns of the Singapore Market

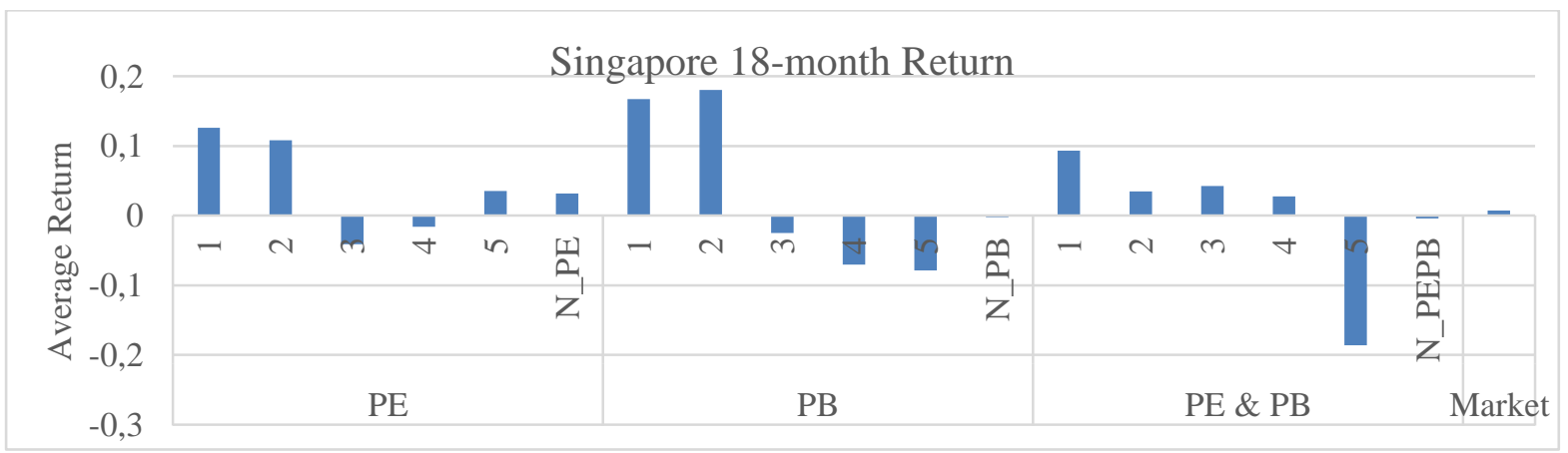

Figure 6 plots value portfolio (Group1) and growth portfolios (Group 5) in risk-return pane. Most value portfolios circled with a normal line locate above growth portfolios circled with a dashed line. This means that with the same level of risk (standard deviation), value portfolios produce higher returns than growth stocks. In other workds, value stocks form portfolios with higher risk-adjusted returns.

\section{Figure 6: Risk-Return Plot for Value Portfolios and Growth Portfolios of the Singapore Market}

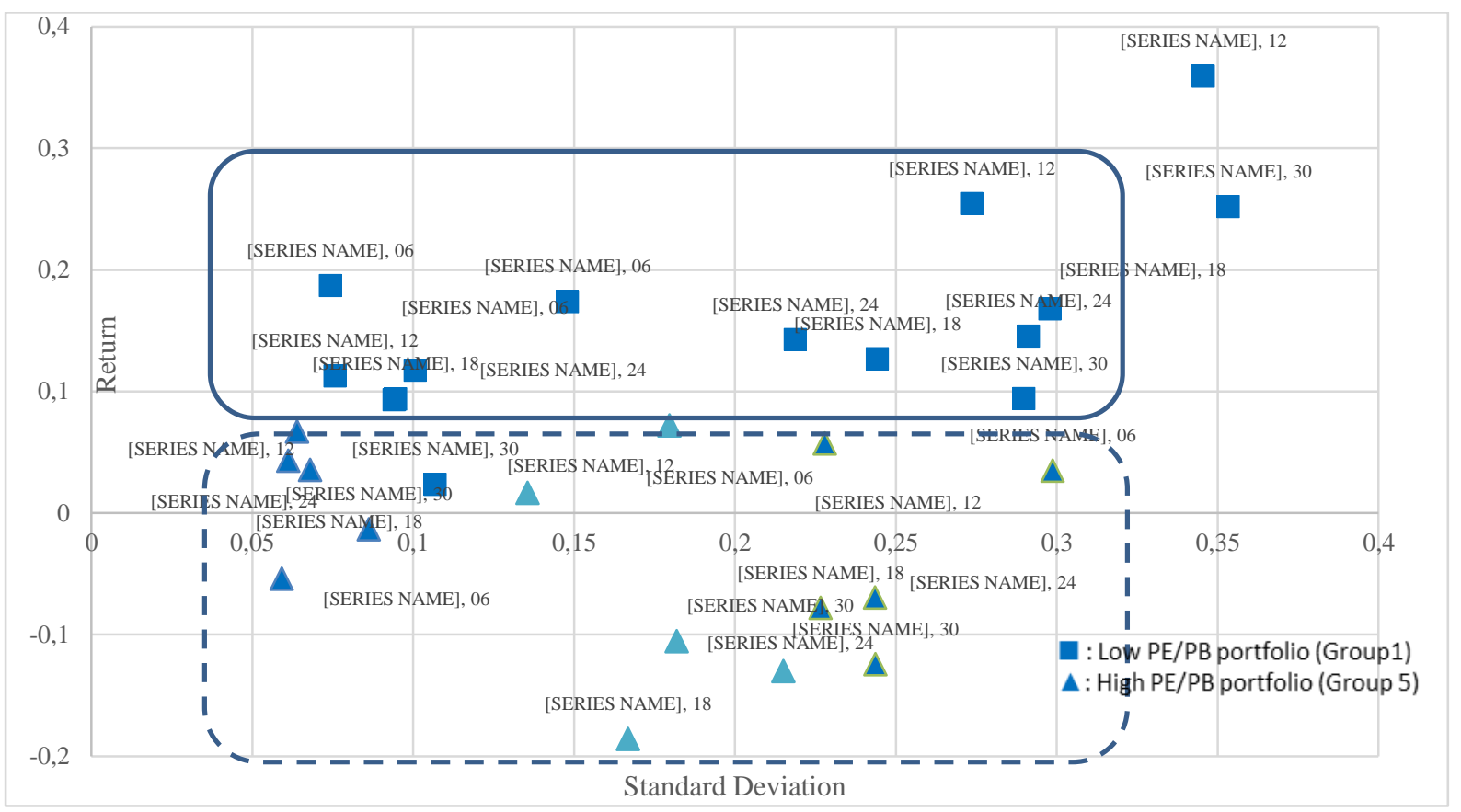


Table 6 reports Fama-Macbeth (1973) regression results. BtM gets positively significant mean coefficient while EY gets negative mean without significance. This indicates that BtM is more reliable value factor in the Singapore market. BtM is positive with significance in 10 out of 14 years. The regression result shows that EY does not possess value premium, which confirms the results of simulation study in Table 5. The more efficient and developed market characteristics in Singapore may be a cause of the insignificance of $\mathrm{EY}$.

\section{Table 6: Regression Results for the Singapore Market}

The table represents the result of Fama-Macbeth (1973) regression. The dependent variable is annualized 1.5-year stock returns. The independent variables are BtM, book-to-market ratio, and $\mathrm{EY}$, earning yield, which are reciprocal of $\mathrm{PB}$ and $\mathrm{PE}$ respectively.

\begin{tabular}{llll}
$\begin{array}{c}\text { Annualized } \\
\text { Year }\end{array}$ & Constant & BtM & EY \\
\hline \hline 2000 & $-0.3658^{* * *}$ & $0.1468^{* * *}$ & 0.2052 \\
2001 & $-0.1781^{* * *}$ & $0.0754^{* * *}$ & 0.007 \\
2002 & -0.438 & $0.1173^{* * *}$ & -0.0035 \\
2003 & 0.0271 & $0.0825^{* * *}$ & -0.0996 \\
2004 & $-0.1271^{* * *}$ & $0.1174^{* * *}$ & $-0.2606^{* * *}$ \\
2005 & $0.0487^{*}$ & $0.0673^{* * *}$ & $-0.3307^{* * *}$ \\
2006 & $0.1386^{* * *}$ & $0.0920^{* * *}$ & -0.0344 \\
2007 & $-0.270^{* * *}$ & $0.050^{*}$ & 0.0026 \\
2008 & -0.2606 & -0.0187 & $0.0695^{* * *}$ \\
2009 & $0.1620^{* * *}$ & $0.0381^{* * *}$ & 0.0155 \\
2010 & $-0.0809^{* *}$ & $0.0214^{* * *}$ & $-0.073^{* *}$ \\
2011 & $-01549^{* * *}$ & 0.0099 & 0.2200 \\
2012 & $0.0711^{* * *}$ & $-0.0079^{* * *}$ & $0.1730^{* * *}$ \\
2013 & $0.040^{*}$ & $-0.0124^{* *}$ & $0.0738^{* *}$ \\
\hline Mean & $-0.0729 * * *$ & $0.0534^{* * *}$ & -0.0137 \\
$* * * * * *$ & denote significance at $5 \%, 1 \%$, and $0.1 \%$ respectively \\
\hline
\end{tabular}

\subsection{The Thailand Market}

Table 7 reports the average returns and standard deviations of the portfolios for the Thai market. The mixed result shows that both value portfolios and growth portfolios generate higher returns than the market with statistical significance. When sorted by $\mathrm{PE}$, the Group 1 portfolio with the lowest PE ratio significantly outperform the market when held for 12 months or longer. Sorting by PB produces the same result, which is the Group 1 portfolios excel with significance for a long term investment. This is different from the two other markets. With the ranking by both $\mathrm{PE}$ and $\mathrm{PB}$, the value portfolio are generally superior to the market in terms of the average return. Nevertheless, their outperformance is statistically not significant except for the Group 2 portfolio with 18-month holding period. Figure 6 and Figure 7 exhibits average returns for all the portfolios for 6-month and 18-month investment horizon. The returns of value stocks as well as growth stocks exceed the market return for the both periods.

Table 7: Average Returns and Standard Deviation of the Portfolios and the Market in Thailand

\begin{tabular}{lllllllll}
\multicolumn{2}{l}{ Portfolio Group } & $\mathbf{1}$ & $\mathbf{2}$ & $\mathbf{3}$ & $\mathbf{4}$ & $\mathbf{5}$ & Negative & Market \\
\hline \hline $\begin{array}{l}\text { Rank by PE } \\
\text { 6-month }\end{array}$ & & & & & & & & \\
& Return & 0.2906 & 0.1641 & 0.0864 & 0.1674 & 0.2503 & 0.0520 & 0.1309 \\
& t-value & 1.1298 & 0.1763 & -0.2563 & 0.1969 & 0.4382 & -0.2056 & -
\end{tabular}




\begin{tabular}{|c|c|c|c|c|c|c|c|c|}
\hline & SD & 0.2525 & 0.1959 & 0.1819 & 0.2423 & 0.3656 & 0.3740 & 0.2378 \\
\hline \multirow[t]{3}{*}{ 12-month } & Return & $0.6050 *$ & 0.2337 & 0.2847 & 0.3657 & $0.6641^{*}$ & 0.6746 & 0.3096 \\
\hline & t-value & 2.4510 & -0.4800 & -0.2122 & 0.4414 & 2.1252 & 0.8772 & - \\
\hline & SD & 0.2232 & 0.1486 & 0.1718 & 0.1921 & 0.3511 & 0.4106 & 0.2339 \\
\hline \multirow[t]{3}{*}{ 18-month } & Return & $0.3808 * *$ & 0.1761 & 0.2653 & 0.2340 & $0.4139 *$ & 0.4396 & 0.1340 \\
\hline & t-value & 2.8624 & 0.3177 & 1.1075 & 1.0472 & 2.4497 & 1.0612 & - \\
\hline & SD & 0.2150 & 0.1262 & 0.1447 & 0.1751 & 0.3142 & 0.3721 & 0.2287 \\
\hline \multirow[t]{3}{*}{ 24-month } & Return & $0.3641 *$ & 0.2401 & 0.2648 & 0.2555 & 0.3781 & 0.4267 & 0.2242 \\
\hline & t-value & 1.7475 & 0.1483 & 0.3767 & 0.3381 & 1.4946 & 0.9153 & - \\
\hline & SD & 0.2064 & 0.1251 & 0.1420 & 0.1574 & 0.2852 & 0.3300 & 0.2264 \\
\hline \multirow[t]{3}{*}{ 30-month } & Return & 0.4998* & 0.2901 & 0.4342 & 0.3319 & $0.5077^{*}$ & 0.8826 & 0.3555 \\
\hline & t-value & 1.8382 & -0.6660 & 0.6734 & -0.2843 & 1.7571 & 1.6580 & - \\
\hline & SD & 0.2114 & 0.1308 & 0.2087 & 0.1586 & 0.2688 & 0.5410 & 0.2176 \\
\hline \multicolumn{9}{|l|}{ Rank by PB } \\
\hline \multirow[t]{3}{*}{ 6-month } & Return & 0.2906 & 0.1133 & 0.1488 & 0.1384 & 0.1240 & -0.1530 & 0.1309 \\
\hline & t-value & 0.4607 & -0.0886 & 0.0922 & 0.0383 & -0.0453 & -1.1146 & - \\
\hline & SD & 0.3789 & 0.2125 & 0.2679 & 0.2754 & 0.3078 & 0.2371 & 0.2378 \\
\hline \multirow[t]{3}{*}{ 12-month } & Return & $0.7356^{*}$ & 0.4642 & 0.3808 & 0.5193 & 0.3827 & 0.8374 & 0.3096 \\
\hline & t-value & 2.0321 & 0.9183 & 0.5894 & 1.7707 & 0.7603 & 1.1519 & - \\
\hline & SD & 0.3172 & 0.2197 & 0.2182 & 0.2564 & 0.2677 & 0.4593 & 0.2339 \\
\hline \multirow[t]{3}{*}{ 18-month } & Return & $0.5443 * *$ & 0.3220 & 0.2738 & $0.3090 *$ & 0.1555 & 0.5697 & 0.1340 \\
\hline & t-value & 2.8946 & 1.5632 & 1.2151 & 1.9950 & 0.3112 & 1.3736 & - \\
\hline & SD & 0.2912 & 0.1972 & 0.1914 & 0.2378 & 0.2510 & 0.3956 & 0.2287 \\
\hline \multirow[t]{3}{*}{ 24-month } & Return & $0.4967 *$ & 0.3398 & 0.2657 & 0.3259 & 0.2557 & 0.4953 & 0.2242 \\
\hline & t-value & 2.0908 & 1.1437 & 0.3795 & 1.3330 & 0.5213 & 1.0934 & - \\
\hline & SD & 0.2621 & 0.1922 & 0.1768 & 0.2185 & 0.2318 & 0.3474 & 0.2264 \\
\hline \multirow[t]{3}{*}{ 30-month } & Return & $0.6283^{*}$ & 0.4440 & 0.3757 & 0.4886 & $0.4386 *$ & 0.8216 & 0.3555 \\
\hline & t-value & 2.3239 & 1.0166 & 0.1954 & 1.6419 & 1.0795 & 2.0753 & - \\
\hline & SD & 0.2626 & 0.1868 & 0.1920 & 0.2293 & 0.2472 & 0.3827 & 0.2176 \\
\hline \multicolumn{9}{|c|}{ Rank by PE \& PB } \\
\hline \multirow[t]{3}{*}{ 6-month } & Return & 0.1454 & 0.1246 & 0.3678 & 0.1929 & 0.1121 & -0.0103 & 0.1309 \\
\hline & t-value & 0.0827 & -0.0353 & 1.5273 & 0.4176 & -0.0419 & -0.6012 & - \\
\hline & SD & 0.2445 & 0.1719 & 0.2181 & 0.2556 & 0.4038 & 0.3215 & 0.2378 \\
\hline \multirow[t]{3}{*}{ 12-month } & Return & 0.4147 & 0.4419 & 0.4688 & 0.3868 & 0.6263 & 0.4277 & 0.3096 \\
\hline & t-value & 0.6728 & 1.1919 & 1.5371 & 0.9980 & 1.1419 & 0.6829 & - \\
\hline & SD & 0.2172 & 0.1910 & 0.2189 & 0.2309 & 0.3232 & 0.2960 & 0.2339 \\
\hline \multirow[t]{3}{*}{ 18-month } & Return & 0.2894 & $0.3575^{*}$ & $0.3288^{*}$ & 0.1950 & 0.3471 & 0.2138 & 0.1340 \\
\hline & t-value & 1.3715 & 2.3517 & 2.1142 & 1.0077 & 1.1193 & 0.6473 & - \\
\hline & SD & 0.1942 & 0.1682 & 0.1929 & 0.2291 & 0.3085 & 0.2652 & 0.2287 \\
\hline \multirow[t]{3}{*}{ 24-month } & Return & 0.2853 & 0.3500 & 0.3297 & 0.2455 & 0.3760 & 0.2471 & 0.2242 \\
\hline & t-value & 0.6007 & 1.3460 & 1.2316 & 0.3781 & 0.9490 & 0.2178 & - \\
\hline & SD & 0.1825 & 0.1570 & 0.1765 & 0.2176 & 0.2810 & 0.2344 & 0.2264 \\
\hline
\end{tabular}




\begin{tabular}{cllllllll} 
30-month & Return & 0.3797 & 0.4420 & 0.4269 & 0.3396 & $0.7854^{*}$ & 0.4387 & 0.3555 \\
& t-value & 0.2637 & 0.9828 & 0.8248 & -0.3050 & 1.9794 & 0.7798 & - \\
& SD & 0.1844 & 0.1647 & 0.1853 & 0.2039 & 0.4170 & 0.2553 & 0.2176 \\
\hline
\end{tabular}

* and ** denote significance at $5 \%$ and $1 \%$ respectively

Figure 6: 6-Month Returns of the Thailand Market

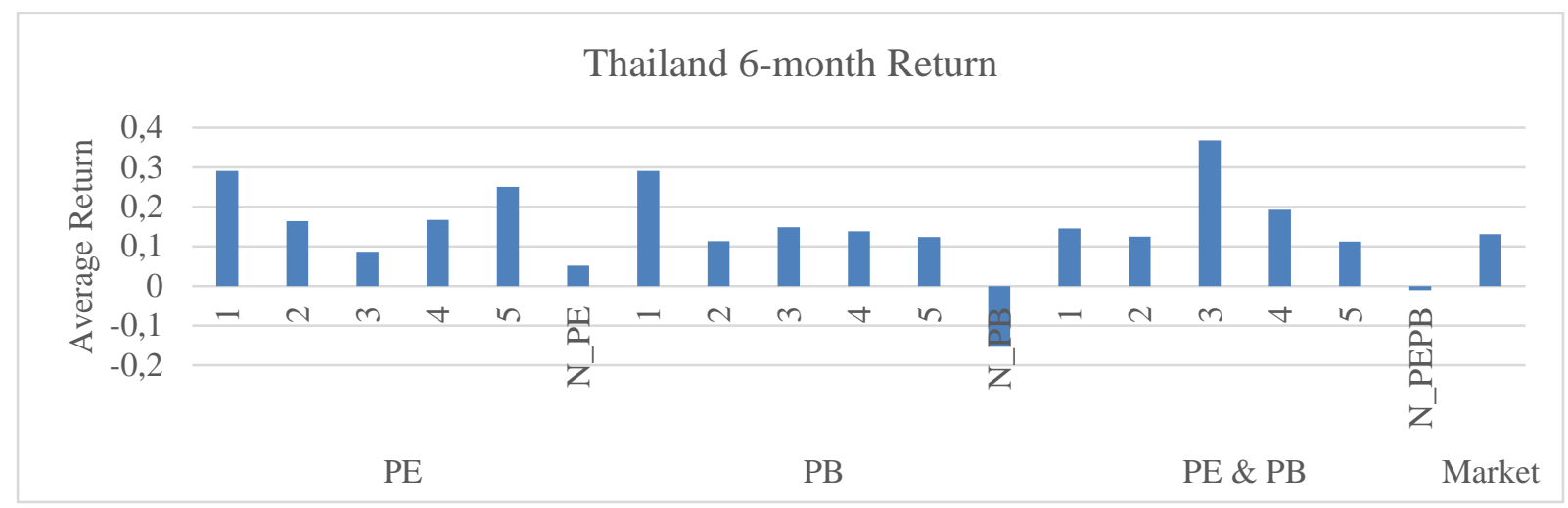

Figure 7: 18-Month Returns of the Thailand Market

Thailand 18-month

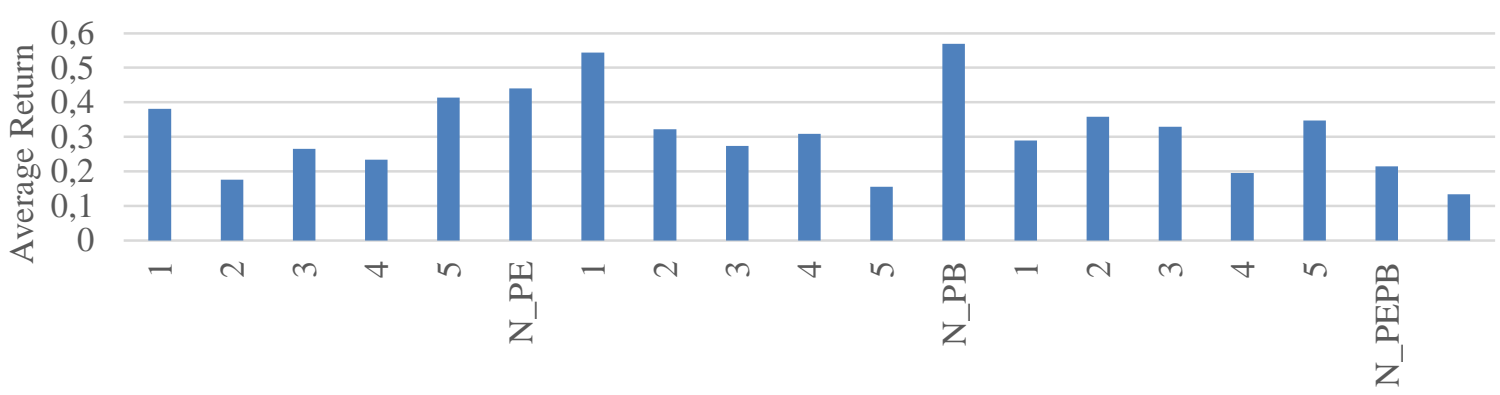

PE

PB

$\mathrm{PE} \& \mathrm{~PB}$

Market

Figure 8 presents risk-return plots of value and growth portfolios in the Thai market. Portfolios circled in dashed line, which are growth portfolios and value portfolios with a short term holding period of 6 months, are less efficient investment because of lower returns given a certain risk. On the other hand, portfolios circled in a normal line, value portfolios with holding period of 12 months or more, generate higher returns with the same degree of risk. Those are clearly more efficient investments.

Table 8 shows the result of Fama-Mcbeth (1973) regression for the Thai market. Similar to the other two markets, the mean coefficient of BtM is positive and significant. BtM demonstrates consistency across the each years, with the positively significant coefficients in 12 years out of 14 years. The mean coefficient of EY is also positive with significance. Looking at the individual years, EY is significantly positive in 8 years out of 14 years. The regression result partly verifies the simulation result of Table 7. However, in the Thai market, both value and growth stocks produce high returns in the simulation, which is not captured in the regression. 
Figure 8: Average Returns and Standard Deviation of the Portfolios and the Market in Thailand

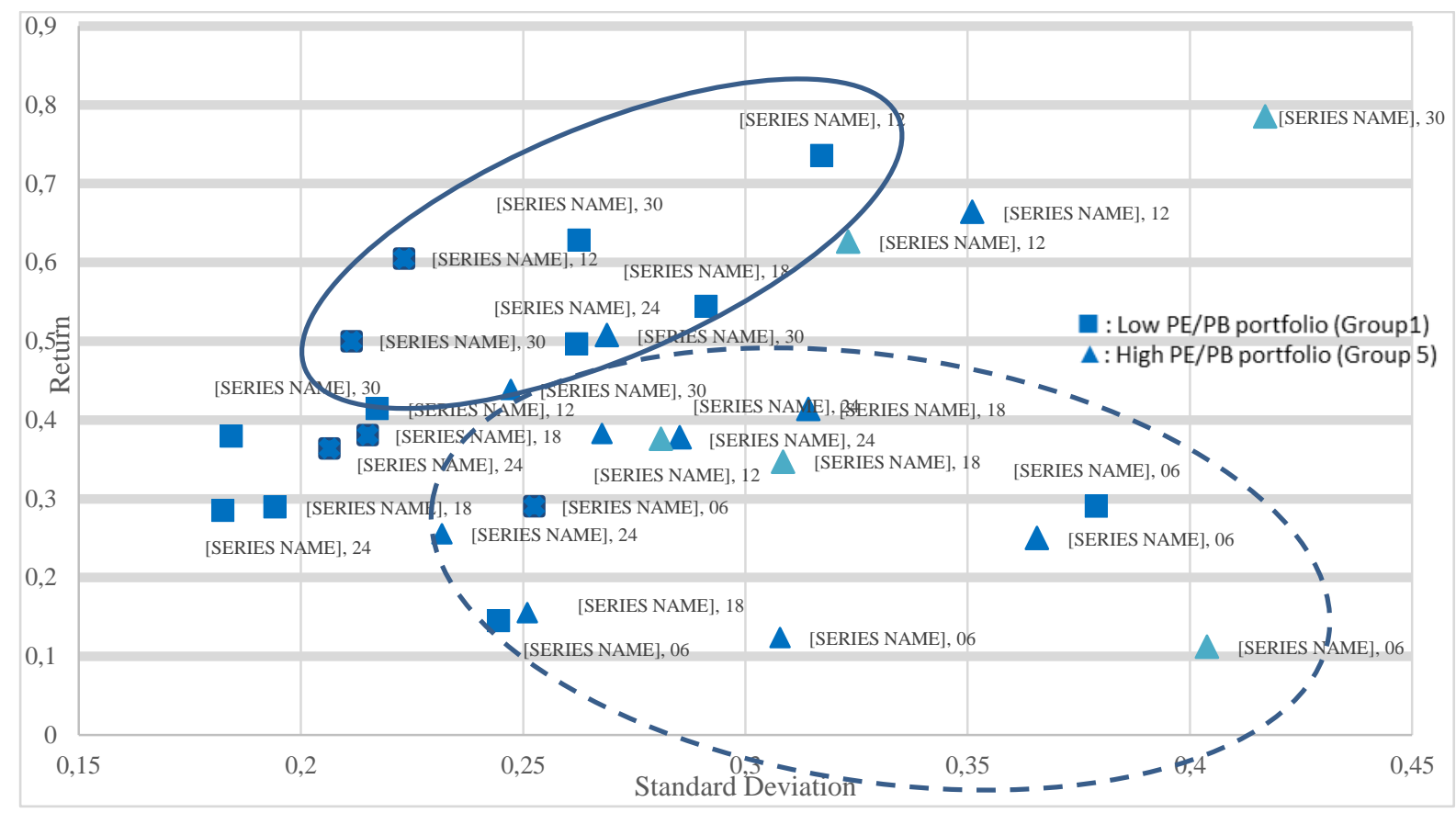

\section{Table 8: Regression Results for the Thailand Market}

The table represents the result of Fama-Macbeth (1973) regression. The dependent variable is annualized 1.5-year stock returns. The independent variables are BtM, book-to-market ratio, and EY, earning yield, which are reciprocal of PB and PE respectively.

Annualized $R_{i t+k}=\propto+\beta_{1} B t M_{i t}+\beta_{2} E Y_{i t}+\varepsilon_{t} \quad k=(18$ months $)$

\begin{tabular}{llll} 
Year & Constant & BtM & EY \\
\hline \hline 2000 & 0.043 & $0.0355^{* *}$ & $0.2597^{* *}$ \\
2001 & $0.2200^{* * *}$ & $0.0070^{* *}$ & $0.0607^{* * *}$ \\
2002 & $0.1621^{* * *}$ & $0.0652^{* * *}$ & $0.1956^{* * *}$ \\
2003 & 0.026 & $0.0789^{* * *}$ & $0.2162^{*}$ \\
2004 & $-0.1633^{* * *}$ & $0.0658^{* * *}$ & 0.044 \\
2005 & $-0.0505^{* *}$ & $0.0289^{* * *}$ & $0.0633^{* * *}$ \\
2006 & 0.0064 & -0.0039 & $0.075^{* * *}$ \\
2007 & $-0.1351^{* * *}$ & -0.0012 & 0.0258 \\
2008 & $-0.1984^{* * *}$ & $0.0264^{* * *}$ & 0.0035 \\
2009 & $0.1604^{* * *}$ & $0.0732^{* * *}$ & $0.0361^{*}$ \\
2010 & $0.1319 * * *$ & $0.0376^{* * *}$ & -0.0026 \\
2011 & $0.0400^{* *}$ & $0.0338^{* * *}$ & $0.2205^{* * *}$ \\
2012 & $0.1997^{* * *}$ & $0.0566^{* * *}$ & $-0.1905^{* * *}$ \\
2013 & $-0.073^{* * *}$ & $0.1336^{* * *}$ & 0.0714 \\
\hline Mean & $0.0244^{*}$ & $0.0495^{* * *}$ & $0.0699 * * *$
\end{tabular}

$*, * *, * * *$ denote significance at $5 \%, 1 \%$, and $0.1 \%$ respectively 


\subsection{The ASEAN Market}

The simulation results for the ASEAN market where portfolios are constructed with all the stocks in the three markets is reported in Table 9. The PE-ranked Group 1 portfolios attain the highest returns for all the holding periods. For PB-ranked portfolios, it is 12 months or longer when the Group 1 portfolios outperform all the other groups. With the ranking by both $\mathrm{PE}$ and $\mathrm{PB}$, the Group 1 portfolios beat Group 5 portfolios for all the holding periods, but it does not provide the highest returns among the groups. Figure 9 and Figure 10 exhibit the average returns for the all portfolios for the holding length of 6-month and 18-month. The outperformance of value portfolios become salient as the investment horizon gets longer from 6 months to 18 months.

Table 9: Average Returns and Standard Deviation of the Portfolios in the ASEAN market

\begin{tabular}{|c|c|c|c|c|c|c|c|}
\hline \multicolumn{2}{|c|}{ Portfolio Group } & 1 & 2 & 3 & 4 & 5 & Negative \\
\hline \multicolumn{8}{|c|}{ Rank by PE } \\
\hline \multirow[t]{2}{*}{ 6-month } & Return & 0.7536 & 0.3432 & 0.5939 & 0.3746 & 0.4340 & 0.6097 \\
\hline & SD & 0.1184 & 0.0348 & 0.1422 & 0.0929 & 0.1286 & 0.1994 \\
\hline \multirow[t]{2}{*}{ 12-month } & Return & 0.3113 & 0.2455 & 0.2933 & 0.1852 & 0.1598 & 0.2140 \\
\hline & SD & 0.1857 & 0.0992 & 0.1543 & 0.1249 & 0.1679 & 0.2372 \\
\hline \multirow[t]{2}{*}{ 18-month } & Return & 0.2327 & 0.2311 & 0.2285 & 0.1807 & 0.1562 & 0.1059 \\
\hline & SD & 0.1619 & 0.0906 & 0.1362 & 0.1126 & 0.1470 & 0.2048 \\
\hline \multirow[t]{2}{*}{ 24-month } & Return & 0.1654 & 0.2013 & 0.2024 & 0.1783 & 0.1813 & 0.1657 \\
\hline & SD & 0.1616 & 0.0866 & 0.1222 & 0.1045 & 0.1345 & 0.1883 \\
\hline \multirow[t]{2}{*}{ 30-month } & Return & 0.1234 & 0.1619 & 0.1634 & 0.1265 & 0.1533 & 0.1399 \\
\hline & SD & 0.1671 & 0.1051 & 0.1284 & 0.1178 & 0.1480 & 0.1845 \\
\hline \multicolumn{8}{|c|}{ Rank by $P B$} \\
\hline \multirow[t]{2}{*}{ 6-month } & Return & 0.4395 & 0.2925 & 0.3867 & 0.3699 & 0.5161 & 0.0927 \\
\hline & SD & 0.1705 & 0.1206 & 0.0979 & 0.1315 & 0.1624 & 0.1086 \\
\hline \multirow[t]{2}{*}{ 12-month } & Return & 0.3339 & 0.2378 & 0.1596 & 0.1200 & 0.1101 & 0.0109 \\
\hline & SD & 0.1654 & 0.1147 & 0.1264 & 0.1495 & 0.2184 & 0.1190 \\
\hline \multirow[t]{2}{*}{ 18-month } & Return & 0.2950 & 0.1989 & 0.1338 & 0.0853 & 0.0975 & -0.0086 \\
\hline & SD & 0.1745 & 0.1027 & 0.1155 & 0.1385 & 0.1813 & 0.1067 \\
\hline \multirow[t]{2}{*}{ 24-month } & Return & 0.1955 & 0.1381 & 0.1432 & 0.0828 & 0.0649 & 0.0547 \\
\hline & SD & 0.1725 & 0.1041 & 0.1017 & 0.1277 & 0.1685 & 0.1301 \\
\hline \multirow[t]{2}{*}{ 30-month } & Return & 0.1662 & 0.1250 & 0.1032 & 0.1008 & 0.0333 & 0.0377 \\
\hline & SD & 0.1817 & 0.0989 & 0.1102 & 0.1506 & 0.1658 & 0.1197 \\
\hline \multicolumn{8}{|c|}{ Rank by PE \& PB } \\
\hline \multirow[t]{2}{*}{ 6-month } & Return & 0.3263 & 0.2553 & 0.3405 & 0.8342 & 0.2032 & 0.4814 \\
\hline & SD & 0.1243 & 0.0738 & 0.1579 & 0.0753 & 0.0960 & 0.2635 \\
\hline \multirow[t]{2}{*}{ 12-month } & Return & 0.1800 & 0.1804 & 0.1510 & 0.3998 & -0.0399 & 0.0888 \\
\hline & SD & 0.1234 & 0.1116 & 0.1385 & 0.1936 & 0.1604 & 0.2343 \\
\hline \multirow[t]{2}{*}{ 18-month } & Return & 0.1604 & 0.1768 & 0.1514 & 0.2473 & -0.0317 & 0.1733 \\
\hline & SD & 0.1136 & 0.0990 & 0.1394 & 0.1775 & 0.1379 & 0.2303 \\
\hline \multirow[t]{2}{*}{ 24-month } & Return & 0.1363 & 0.1704 & 0.0764 & 0.1976 & -0.0340 & 0.1512 \\
\hline & SD & 0.1209 & 0.0898 & 0.1352 & 0.1590 & 0.1269 & 0.2066 \\
\hline \multirow[t]{2}{*}{ 30-month } & Return & 0.0878 & 0.1457 & 0.0365 & 0.1993 & -0.0502 & 0.1306 \\
\hline & SD & 0.1334 & 0.1058 & 0.1423 & 0.1532 & 0.1409 & 0.1909 \\
\hline
\end{tabular}


Figure 9: 6-Month Returns of the ASEAN Market

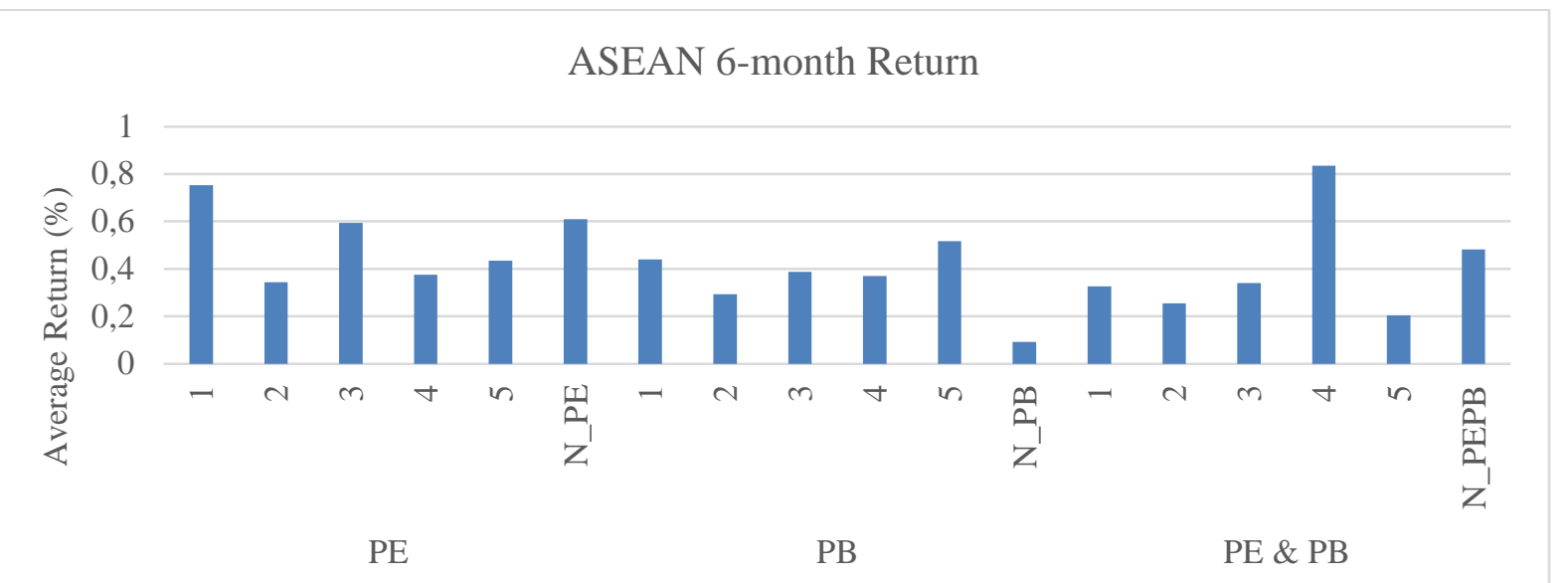

Figure 10: 18-Month Returns of the ASEAN Market

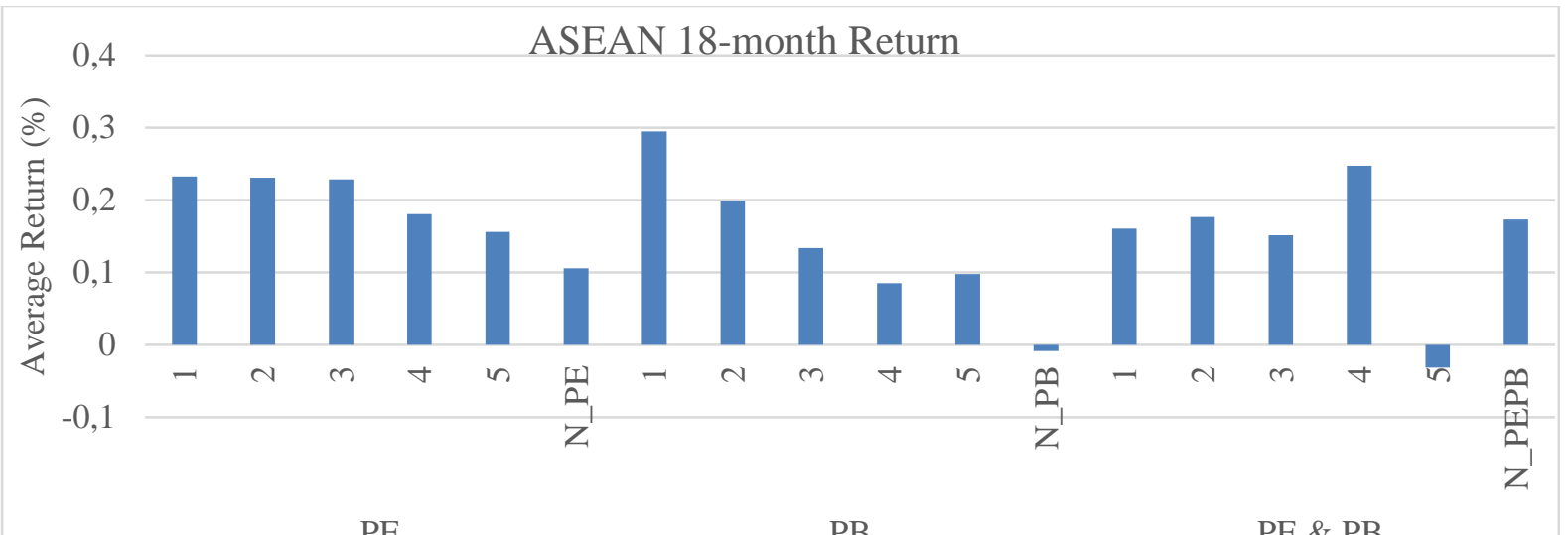

PE

PB

PE \& PB

Figure 11 plots the Group1 value portfolios and Group 5 growth portfolios in risk-return pane. The advantage of international diversification is clearly seen. The standard deviation of the majority of the portfolios in the ASEAN market as a whole is well below the $20 \%$ mark. On the other hand, when the portfolios are formed within the single market, many portfolios' standard deviations easily surpass $20 \%$ as indicated in Figure 3, Figure 6 , and Figure 8 . The portfolios in the normal circle line in Figure 11, which are mostly consisted of value stocks, form efficient portfolios. The less efficient portfolios are within the dashed line circle are mainly constituted by growth stocks, which yield less return at the same degree of risk. 
Figure 11: Average Returns and Standard Deviation of the Portfolios in the ASEAN Market

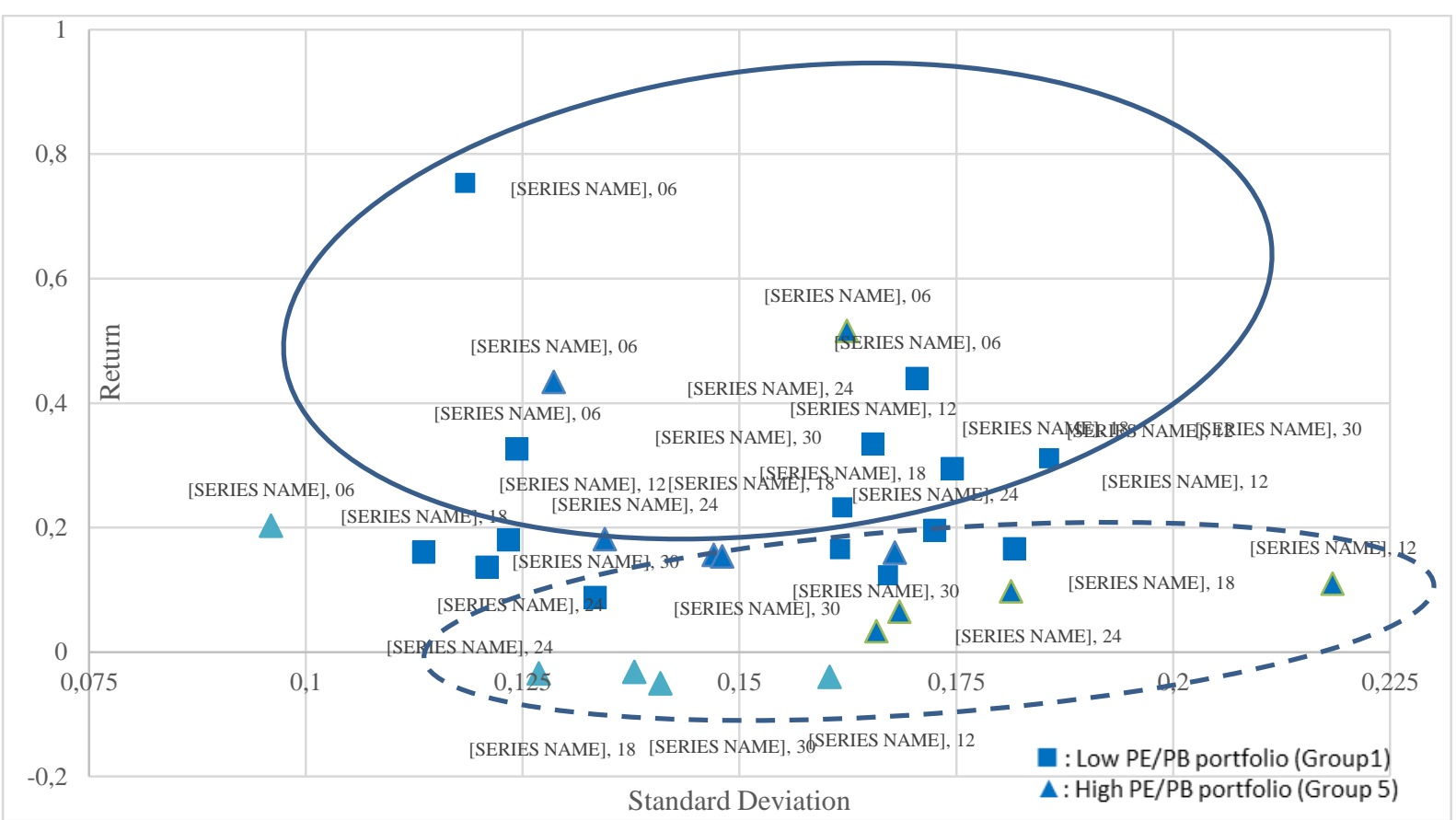

\section{CONCLUSION}

This research aimed to test value investing in the three markets in the Southeast Asia using simulation study methodology. On the randomly selected dates, stocks are ranked according to PE and PB ratios, simple but popular indicators of value premium, then portfolios are built by the rank. In addition, returns are obtained for different investment lengths to see whether value investors are rewarded for holding stocks for a longer period of time. Advantage of international diversification through the ASEAN Link is also examined.

The results indicate that long-term value investing is an effective investment strategy in the ASEAN markets although the outcome is not the same for the each market. In the Malaysia market, all the portfolios sorted by PE, PB, and both PE and PB post superior performance with statistical significance for the investment horizon with 18 months or longer. In Singapore, value portfolios manage to outperform the growth portfolios but lack statistical significance. The gap in return between value and growth portfolios becomes wider as the holding period gets longer. In the Thai market, both value and growth portfolios interestingly beat the market. The value portfolios attain the statistically significant higher return when the stocks are held for 12 months or longer. The robustness of simulation results is checked by Fama-Mcbeth (1973) regression, which satisfactorily supports the outperformance of values stocks in a long term investment. The portfolios constructed from all the stocks in the three markets all have low standard deviations but not necessarily lower returns, an evident benefit from international diversification. This is a key contribution of this study which should encourage the investors in the region to hold more stocks from other markets besides their home country. Another important finding is that value stocks form more efficient portfolios, which risk-return trade-off is in a more favorable state. On the contrary, it is the growth stocks that constitute inefficient portfolios where taking extra risk is not rewarded with higher return.

Only PE and PB are employed for screening stocks in this research, but future research can be done using variables other than these two, such as market cap, dividend yield or ROE for example. At the time of the writing, only Malaysia, Singapore, and Thailand are integrated in the ASEAN Link, but other markets in the Southeast Asia such as Vietnam and Indonesia, are expected to join the system in the future, and they may add more values in terms of diversification. 


\section{REFERENCES}

Ammann, M. \& Verhofen, M. (2006). The Effect of Market Regimes on Style Allocation, Financial Market and Portfolio Management, vol. 20, no. 3, pp. 309-337.

Banz, R. (1981). The relationship between returns and market value of common stocks. Journal of Financial Economics, vol. 9, no. 1, pp. 318.

Basu, S. (1977). Investment Performance of Common Stocks in Relation to Their Price-Earnings Ratios: A Test of the Efficient Market Hypothesis. Journal of Finance, vol. 32, no. 3, pp. 663-682.

Black,A. \& McMillan, D. (2004). Non-linear Predictability of Value and Growth Stocks and Economic Activity, Journal of Business Finance \& Accounting, vol. 31, no. 3-4, pp. 439-472.

Black,A. \& McMillan, D. (2005). Value and Growth Stocks and Cyclical Asymmetries, Journal of Asset Management, vol. 6, no. 2, pp. 104116.

Bauman, W.S., Conover, C.M., \& Miller, R.E. (1998). Growth versus Value and Large-Cap versus Small-Cap Stocks in International Markets. Financial Analysis Journal, vol. 54, no. 2, pp. 75-89.

Chan, L., Hamao,Y., \& Lakonishok, J. (1991). Fundamentals and Stock Returns in Japan. Journal of Finance, vol. 46, no. 5, pp. 1739-1764.

Chen, L. \& Petkova, R. \& Zhang, L. (2008). The Expected Value Premium, Journal of Financial Economics, vol. 87, no.2, pp. 269-280.

Fama, E.F., \& French, K.R. (1992). The Cross-Section of Expected Stok Returns. Journal of Finance, vol. 47, no. 2, pp. 427-465.

Fama, E.F., \& French, K.R. (2015). A Five-Factor Asset Pricing Model. Journal of Financial Economics, vol. 116, no. 1, pp. 1-22.

Fama, E. and MacBeth, D. (1973). Risk, Return, and Equilibrium: Empirical Tests. Journal of Political Economy, vol. 81, no. 3, pp. $607-636$.

Gaudecker, H. (2015). How Does Household Portfolio Diversification Vary with Financial Sophistication and Financial Advice? Journal of Finance, vol. 70, no. 2, pp. 489-507.

Graham, B. (1949). Intelligent Investor. New York: HarperCollins.

Gulen, H. \& Xing, Y. \& Zhang, L. (2011). Value Versus Growth: Time-Varying Expected Stock Returns, Financial Management, vol. 40, no.2, pp. 381-407.

Lessard, R. (1976). World, Country, and Industry Relationships in Equity Returns-Imprecations for Risk Reduction Through International Diversification. Financial Analysis Journal, vol. 32, no. 1, pp. 32-38.

Markowitz,H. (1952). Portfolio Selection. Journal of Finance, vol. 7, no. 1, pp. 77-79.

Muller, C. (1999). Investor Overreaction on the Johannesburg Stock Exchange. Investment Analysts Journal, vol. 49, no. 28, pp. 5-17.

Novy-Marx, R. (2013). The Other Side of of Value: The Gross Profitability Premium. Journal of Financial Economics, vol.108, no.1, pp. 1-28. Rousseau, R. \& Rensburg, P. (2004). Time and the Payoff to Value Investing. Journal of Asset Management, vol. 4, no. 5, pp. 318-325.

Sareewiwatthana, P. (2013).Common Financial Ratios and Value Investing in Thailand. Journal of Finance and Investment Analysis, vol. 2, no. 3, pp. 3-18.

Sarwar, G. \& Mateus, C. \& Tadorovic, N. (2017). A Tale of Two States: Asymmetries in the UK Small, Value, and Momentum Premiums, Applied Economics, vol.49, no.5, pp 456-476

Slonik, B. H. (1974) Why Not Diversify Internationally Rather Than Domestically? Financial Analysis Journal, vol. 30, no. 4, pp. 48-54. 